\title{
Research on Customs Administration to Cross-Border Electronic Commerce Importation under Taxation Measurement
}

\author{
Fan Li \\ School of Public Administration, Jinan University, Guangzhou, China \\ Email: tqtbxft@hotmail.com
}

How to cite this paper: Li, F. (2017) Research on Customs Administration to Cross-Border Electronic Commerce Importation under Taxation Measurement. American Journal of Industrial and Business Management, 7, 581-590.

https://doi.org/10.4236/ajibm.2017.75043

Received: April 12, 2017

Accepted: May 14, 2017

Published: May 17, 2017

Copyright $\odot 2017$ by author and Scientific Research Publishing Inc. This work is licensed under the Creative Commons Attribution International License (CC BY 4.0). http://creativecommons.org/licenses/by/4.0/

\begin{abstract}
As a new trading model, Cross-Border Electronic Commerce becomes an important tool to motivate the transformation and upgrade of economics. The Taxation Measurement on Retail Import of Cross-Border Electronic Commerce ("Taxation Measurement") approved by the State Council was implemented on April 8, 2016. This essay will review the implementation of the taxation measurement from customs perspective; discuss the customs administrative issues after the implementation and conduct an analysis on the reasons for the issues, so as to explore solutions and new customs administration model, which could be applied to the development of Cross-Border Electronic Commerce model. Consequently, to practice customs administration more efficiently and facilitate the trade model would become realizable.
\end{abstract}

\section{Keywords}

Tax Measurement, Cross-Border Electronic Commerce, Retail Import, Customs Administration

\section{Introduction}

Cross-border e-commerce is a business mode that is combined and developed by electrical commerce and international trading. Through informational means of telecommunication like internet, this form of international trading business activity completes all the steps of trade which includes trading, settling payment and delivering commodities via cross-border logistic. It's a new type of trade format developed from the combination of electrical commerce and international trading. In recent years, under the main trend of "Internet + development", our country has shown a booming economic growth. The rapid development of cross-border e-commerce has agreed with the call of "mass entrepreneurship 
and innovation". Cross-border e-commerce, especially under the current stern situation of foreign trade, is growing into a preferential foreign trading mode for small and medium-sized enterprises; thus providing an important method for them to transform and upgrade. It will also become a significant supplement of traditional foreign trading and the evident trend of future development.

Cross-border e-commerce is a rapid-growing new business format with the characteristics of virtualized, globalized, anonymous and paperless. In late years, our country has taken active measures to encourage its development and achieved first-stage success. At the beginning of the year 2016, shortly after the establishment of the China (Hangzhou) Cross-border e-commerce comprehensive pilot area by the State Council in March 2015, permission is granted by the State Council to form cross-border e-commerce comprehensive pilot areas in 12 cities including Guangzhou and Tianjin. This symbolizes a new developing stage for this new form of business, and helps solve the deeply rooted contradictions and structural problems in the development of cross-border e-commerce.

Nevertheless, resulted from the considerable discrepancy of the trading format between cross-border e-commerce and traditional international trading, crossborder e-commerce has not yet been adapted by current customs mode of management, especially after the implement of new taxing policy in April 2016, Although promoting the new policy has a significant meaning, the flourishing business of cross-border e-commerce is experiencing "the growing pain".

In order to supervise the import-export commodity of the e-commerce as well as to advance its development in a healthy and orderly fashion, on $24^{\text {th }}$ March, the Ministry of Financial, General Administration of Customs, State Administration of Taxation made a joint announcement that the Tax Policies on CrossBorder E-Commerce Retail Imports (hereinafter referred to as the new tax policy) would be put into effect from $8^{\text {th }}$ April; and that the "positive list" of the first and second shipment of Cross-Border E-Commerce Imports would come into existence on $7^{\text {th }}$ and $15^{\text {th }}$ April respectively. The framework of 1240 commodities under the eight-digit HS code was also issued. According to the new tax policy (Mainly "Announcement of the General Administration of Customs on Issues Concerning the Regulation of Goods and Articles Entering and Exiting China through Cross-Border Trade E-Commerce", Announcement No. 26 [2016] of the General Administration of Customs, hereinafter referred to as the announcement No. 26), commodities entering China through cross-border trade e-commerce would be taxed by a unitary tax composed of tariff, value-added tax and consumption tax, which replaced the original parcel tax; the limit of a single cross-border transaction was adjusted from $1000 \mathrm{RMB}$ to $2000 \mathrm{RMB}$; transaction within the limit would be exempted from tariff, while only $70 \%$ of the tax payable would be levied from the import VAT and consumption tax. At the same time, the policy regarding tax waiver for articles with an import duty payable of RMB 50 or less would no longer be implemented. Transaction exceeding the limit would be levied the full tax for general trade. On $24^{\text {th }}$ May, the General Administration of customs announced that in the pilot cities including Guang- 
zhou, a 1-year transition period for executing the new regulation of the import commodities through cross-border trade e-commerce would be carried out. At the same time, the parcel tax of the retail imported goods would also be adjusted accordingly to coordinate with the new tax policy; the previous 4 gear taxable items (corresponding tax rate: $10 \%, 20 \%, 30 \%, 50 \%$ ) would alter to 3 (corresponding tax rate: $15 \%, 30 \%, 60 \%)$.

In general and long term speaking, the promotion of the new tax policy has created a consolidated environment for tax policy and a fair competition in the market for the development of the cross-border e-commerce, while put off the uncertainty of the future development of this business in terms of tax policy; this favored enterprises to plan long-term developing strategies and business plans of investment. However, the new tax policy was carried out in a rush before the existing core problems such as customs clearance could be solved, causing a "huge shock" in the industry.

\section{Analysis}

The new tax policy raised enormous awareness from the media before and after its implementation. The industry's general concern was that the development of the trade would be suppressed; the consumers worried about the increasing price of the e-commerce commodities; and Customs, as a supervising department, found things to "whine about" in execution. Mainly reflected in:

(1) The new policy did not make the situation of double taxation ${ }^{1}$ better; on the contrary it intensified the tax administration and increased the difficulty of supervision. As reflected by the industry, some showed an obvious "impulsion" to shift direct purchased cross-border commodities (mainly "polarized goods" with "low value" and "high value") to personal effects, i.e. shifting cross-border commodities with the value of less than RMB 330 to personal effects to enjoy the tax waiver for articles with an import duty payable of RMB 50 or less; shifting cross-border commodities with the value of more than RMB 2000 to personal effects to avert the limitation of single cross-border transaction from the new tax policy. This situation has enhanced the heavy burden that the supervising Customs were originally having. On one hand the importing number of personal effects had surged in a short period of time and rather separate, the Customs had to constantly fill in manpower and work overtime for supervision. Under the premise that the current mode failed to satisfy the rapid growth of need for customs clearance, the workload of customs officers largely increased, resulted in a poor logistic effectiveness experience, causing congestion in customs clearance. On the other hand, shifting cross-border commodities to personal effects might initiate unlawful merchants to "break down whole into parts" and smuggle. Originally, there were some bulky and centralized imported goods, with higher value and should be levied from commodity tax, yet some unlawful enterprises turned these goods into separated, with low single value, low taxed or duty freed personal effects or samples. They only paid the parcel tax and evaded the payable

${ }^{1}$ Double taxation refers to parcel tax and commodity tax. 
tariff, VAT and consumption tax. Some with ulterior motive even found a loophole and took advantage of the principle of "private use" and "reasonable amount" to split the order and deliver some sensitive commodities in order to avoid supervision of the customs, causing the officers great pressure and larger risk of misconduct.

(2) Under the influence of both tax policy adjustment and positive list requirement, industry reshuffle might be further intensified. According to the new tax policy, there will be a decrease in the tax of imported commodities with the price range from RMB 100 to RMB 2000 such as cosmopolitans, toiletries and watches; and as for the formerly principle goods for everyday consumption of cross boarder e-commerce within RMB 500, which was applied to the $10 \%$ tax rate, especially the maternal and child products, they have increased in business operating cost or consumer buying cost, as a result of the increase of tariff, VAT and consumption tax. Therefore, most companies would further adjust the category of their imported goods in order to lower the cost of operation and maximize the industry profit. Industry reshuffle was unavoidable. On top of that, import of general trade had a bulky order, the cost of transportation was comparatively lower, so much that the import tax of general trade would be cheaper for some low-priced goods such as maternal and child products, shoes and clothes than that of the cross-border e-commerce. Take Yiwu, an important base for the cross-border e-commerce import of our country as an example, "At present, most types of the cross-border e-commerce commodity in Yiwu are products like cosmopolitan, red wine, olive oil and milk powder, with the tax rate of $10 \%$ and with reasonable tax avoidance; but the profit of such goods can hardly overpass $10 \%$. It is estimated that after the tax reform, most of these small cross-border businesses will face elimination [1]. Secondly, the two positive lists announced had established boundaries for business area of the cross-border e-commerce platform, the platform itself had to readjust its business according to its feature, which is quite a challenge for the e-commerce enterprise.

(3) Outbound companies are unable to participate in the business of crossborder e-commerce, there is a trend for cross-border service business to shifted overseas. The announcement No. 26 has a clear regulation regarding business management: "Enterprises that participate in cross-border e-commerce should submit a photocopy of the original duplicate of Organization Code Certificate, and business license of enterprise legal person, to the on-site customs ...", this means cross-border e-commerce enterprises cannot complete the information registration if they do not register within the boundary of China, hence cannot continue their cross-border business. Despite the fact that the announcement no.26 also states that "Inward and outward express consignment operator and postal enterprise can be entrusted by e-commerce business and pay business, under the premise that with a written promise to bear relative legal liability of the reality of the data transited, they can transit electric information such as transaction and payment to the customs", nevertheless, as outbound companies cannot complete the information registration in the customs to retrieve the 
number of recordation, they in fact cannot promote their business through the commission. For instance, "Amazon (USA)", a well known and widely influential e-commerce enterprise in the industry, has quite a big consumer group in China; but it is restricted by the law of its own country, even though it can entrust Chinese domestic enterprise to register at the customs, Amazon (USA) and the foreign payment institution failed to provide relative business material and electric data to the Chinese customs, influencing its cross-border e-commerce retail import business.

Meanwhile, affected by the new tax policy, the business showed less than 30\% of the operating rate at the bond warehouse, the prior invested automation equipment are starting to be put aside, some service companies are beginning to lay off employees. In comparison, since the overseas warehouses can continue to enjoy policies such as tax exemption, negative list managing mode and non-requested customs clearance etc., the rent of the overseas warehouses in places like Hong Kong, Taiwan and Vietnam has a substantial increase within one month, the business is on fire. According to Tmall Global, the price of the overseas warehouses in Hong Kong has raised to RMB 150 - 170 per square meter, which is 5 - 6 times of the bonded warehouse in Hangzhou. The hope of entering the cross-board industrial chain through providing trade in service to oversea e-commerce and form an industrial agglomeration of various crossboard zones will be lost. We will go back to purchasing services overseas, or worse, grey customer clearance and purchasing broker might rise from the ashes, causing loss to taxation.

\section{Reasons}

The reasons for the above problem are manifold, which can be induced to a major reason that it is difficult for the system and the management concept of customs to adapt to the development of the emerging trade format, it still holds the habit of doing management relying on traditional way of thinking, satisfied with "tinkering" instead of try to solve the bottleneck problem of restricting efficient supervision of the customs.

(1) The system still needs to be consummated. First, Because of the absent of the unified higher law, the customs supervision department of the pilot cities, when dealing with cross-border e-commerce, lack unity from the understanding of the legal basis to the execution of the actual operation. These departments execute the standard of law enforcement base on their individual understanding, Second, in 2016, the General Administration of Customs announced the Announcement No. 26 ("Announcement") to make it more clear that the management requirements of the cross-border e-commerce such as enterprise management, customs clearance management, management of purchase return, tax levy management, logistic monitor, etc. Yet the Announcement still lacks the regulation and the detailed rules of operation. In cross-border commerce, some aspects, like the examining of shipping document, tax guarantee, customs supervision, management of purchase return and so on, work are still being carried out 
base on experience, which is unfavorable to standardize and unified law enforcement. Third, aspects outside the main process, such as the price inspection, tax refund operation, etc., are still short of normative document; their management regulation, like operation procedure, inspection requirement, documents management, to name a few, is still in a blank state. As a result, the customs will have no specific basis to rely on, it will have more discretionary power, and the efficiency of customs clearance will be restricted, resulting to the increase of the difficulty and risk for the customs officers to manage and operate.

(2) Inconsistent of the import tax system is resulted from the lack of effective management system, which has aroused controversy repeatedly. First of all, as an emerging trade format, the cross-border e-commerce requires the supervising service of the customs to adapt its special characteristics of business, which is determined by the distinguishing features of the cross-border e-commerce business such as high efficiency, great need for data processing, multiple subjects involved and deficient of the self-administrating system of business, etc. Nowadays, there are still no official laws and regulations for managing the vigorously surging cross-border e-commerce business, various ways for customs clearance supervision can be found in legal provisions from different levels, without the regulation of the corresponding laws, there is a larger in-certainty in the policy of the laws. The new tax policy seems like "a cock crows at midnight", added with the unclear policy after the 1-year transition period, making the e-commerce companies hard to follow, plus there are no timely interpretation from the authorities nor the guidance from the mass media after the published of the new tax policy, causing doubts and misunderstandings from the people.

Moreover, the co-existence of parcel tax and commodity tax has always been criticized as it levies different taxes to the same types of imported goods; it is widely controversial, especially under the circumstance that the volume of business of the cross-border e-commerce is constantly growing. The outcome of the market fragmentation of the cross-border e-commerce is that the conventional large quantities of products delivery has turned into a small quantities of goods transportation; customs is now facing individuals rather than enterprises, which makes the boundary between products with trade attribute and with non trade attribute more and more indistinct. Even if the new policy levies tax through commodity tax, owing to the unique rule of the policy, the industry is still used to call that "e-commerce tax" to show the difference.

(3) Backward philosophy of supervision, emphasize on controlling and overlook service, hence unable to fulfill the market need that is constantly growing. In terms of the actual supervision from the previous years, Customs supervision to the cross-border e-commerce business is focus on controlling and stanching the leaks. They do very little in confronting reasonable request from the people, as well as adjusting and perfecting respective regulations [2]. The implement of the new tax policy has once again proved the above view. Starting from last year, the hearsay about the country will release a new cross-border e-commerce tax policy has been uproar in the city; enterprises have "dreamed longingly", yet the 
policy was undecided. The rules of the new policy and positive list were only published right before the implementation, which stupefied the enterprises and the consumers; even the supervising departments like the customs were caught by surprise, they didn't have the time to come up with supporting measures for the operation, let alone renewed and converted the information supervision system on time. At the end of the day, these were caused by the backward of the management philosophy.

"Service and control are not two opposing concept, emphasize on service does not mean we don't have control or don't need control" [3]. It is impossible for a sophisticated philosophy of supervision to only choose control and not service, vice versa; the way is to closely combine the two together. In terms of the work of customs, service should be enhanced in a down to earth manner, like "We should improve and perfect the rights protection system of the tax-payers, broadly speaking, tax-payers' rights include the rights to access, to know, to participate, to supervise and to request the tax" [4]. Only with a good grasp of good service and professionalism of the customs can we lead the cross-border ecommerce trade to a healthy and orderly development.

(4) Customs are not used to the supervision mode of the cross-border ecommerce trade. The design of the traditional customs management system is bounded by the supervision philosophy and limitation of technique; it focuses on the regulatory affairs of the exporting goods. At present customs have basically inherited the conventional management style to goods when managing cross-border e-commerce, in other words the operation flow of "declare-verify-examine-clearance", they have only added a link of verification in declare and verify called the " 3 info" comparison ${ }^{2}$, but still give priority to the management of the real-time clearance in the aspect of mode; focus on the ticket by ticket clearance when verifying cross-border commodities; and they still use the medium of service and conventional professional foreign trade enterprise as the management policy measure to the regulatory objects. However, the cross-border e-commerce business is different from the trading of the conventional goods, it has the characteristics of high informatization, subject diversification, trade fragmentation and logistic diversification; which is bound to create impact on the traditional customs system which centralizes on the regulatory affairs.

\section{Countermeasure}

According to the modern economic theory, market is the "invisible hand", "Pareto optimality" can be achieved through resource allocation. Though it can only be realized in a very harsh premise, it is almost impossible for that to happen in real market, that's why when the problem of Market failure occurs or when the market is limited, Government departments will have to take corresponding supervising measures to restrict and regulate the business activities in the market. "Government should provide benefit and convenient for the tax and clearance of

2 "3 info" comparison refers to transaction information, payment information and logistic electronic information. 
the cross-border e-commerce enterprises, and progressively set up standards and regulations of business to guild the development of the cross-border e-commerce industry, in order to promote a regulatory and healthy development of the cross-border e-commerce industry" [5]. The management of Government departments including the Customs must blaze new trails in order to face the emerging trading format of cross-border e-commerce; Innovation in management can adapt and boost the growth of the market, as determined by the urgency of management innovation. This requires the customs to make an all-round transformation in its supervising methods; make feasible change in the function of management; build up a new customs supervision mode including a sound system, a unified tax system, a big data center and a implementation mode, that can adapt to the cross-border e-commerce; finally create a healthy and favorable environment for the business development.

(1) Construct a sound system. In the regulatory level of the State Council, base on the feature of the industry, pay close attention to furtherance the published of the "e-commerce law", regulates the electronic commercial activities with the foundation of law, enhance the top-level design. In the level of departmental regulation, customs should take the lead and learn from the experience of the new tax policy, make adequate consideration in terms of the special taxation of the cross-border e-commerce and details of the implement; build up a sound taxation management system and measures for the cross-border e-commerce. In the level of the specific enforcement operation, complete the supporting policies play the guiding function of the policy. For instance, "We can consider providing tax incentives to eligible e-commerce enterprises; issue a catalog of necessaries of life of the e-commerce that enjoys the preferential policy" [6].

(2) Create a unified tax system, although in the form of the cross-border e-commerce there is an attribute difference between parcels and commodities, in nature it is still a type of trading. From the point of trade fairness, it should be suitable for cross-border e-commerce to us the same trading management as conventional trading; at the same time it can help prevent conventional trading from transforming into cross-border e-commerce, so as to put difference in place and develop together. Therefore, when considering the measure of customs management, organic unify, as requested by the tax system and supervision of various forms of trading, should be achieved. Firstly cross-border e-commerce should have a unified taxation and supervision with the conventional trading to avoid the large influx of conventional trading to the cross-border e-commerce business; Secondly, there should also be a unified taxation and supervision of the parcels and express items to prevent the cross-border e-commerce from flowing into irregular channels such as overseas online shopping and overseas purchasing through agents, which are outside the regulation.

(3) Build up a big data center. As a business that is closely related to internet, cross-border e-commerce has all kinds of connection with technical data. Through broadening the base area, perfecting the measures and unifying the standard of data collection, a comprehensive and standardized business data 
collection system will be formed. By building up a big data analyzing platform that combines deeply with the business, the value of the data can be tapped thoroughly; which is favorable for the foundation of the densification of customs data-based supervision, providing data support to the work of on-site enforcement.

(4) Forge a implementation mode of "forward-moving and backward-shifting". To conform to the request for unified reform of the customs clearance of the country, the idea of "record beforehand, let go during operation, verify afterwards" is carried out to realize the efficiency of law enforcement through moving forward and shifting backwards. In the beforehand stage, the e-commerce enterprises provided a filing application to the customs regarding the classification of goods; during clearance, the customs gave a fast pass to the data list that had been put on record in advance, at the same time conducted necessary sporadic verification; in the afterwards stage, customs would check the withholding agents regularly, the checking result would be used as the basis of classification management of enterprises, and used in the supervision link at the beforehand stage.

\section{Conclusions}

Cross-border e-commerce was found more than 10 years ago, but the rapid development of this business in our country has only started for 2 - 3 years, and at present it is getting well-developed. The development of the new form of trading has indeed provided a new growing point for the foreign trade economy of our country. But at the same time, it has brought out a new challenge for the departments that manage the entering and leaving of our country, as represented by the customs. In recent years, the General Administration of Customs, as well as customs of every level, has given their full support in developing the crossborder e-commerce. For instance, in January 2014, Adding a Customs Supervision Model Code "9610" was announced; customs supervision model code "9610" standing for "e-commerce in cross-border trade" has been added; in July 2014, the Announcement on Adding a Customs Supervision Model Code was announced; customs supervision model code "1210" standing for "bonded e-commerce in cross-border trade" has been added. Nevertheless, according to the result of the research, what trade format management of this kind of needs is an all-rounded, revolutionary reform? Through a series of systems and management reforms, we can provide a healthier and more harmonious internet trading "ecological environment" for the market subject, we can also forge a new international trading rule system that tallies with the developing trend of "internet + foreign trading" and raise the international competitiveness and discourse power of the e-commerce business enterprises of our country.

We shall look at the problems generated from the new tax policy, study and analyze the related causes and rethink the insufficiency of the whole customs management model, then bring forward the corresponding measures, in which some are coming true progressively, such as the information construction. This 
is the main contribution of the research.

The limitation of the research is that since this research is mainly based on Guangzhou city, some problems mentioned might not be common. Also, the reform of the cross-border e-commerce is presently entering the "profundal zone", not only is it related to the customs, it is also related to government departments like General Administration of Quality Supervision, Inspection and Quarantine of the People's Republic of China, State Administration of Taxation and State Administration of Foreign Exchange. The discussion in this essay mainly focuses on the supervision of customs; this is a shortcoming which is hoped to be compensated in further research through a higher perspective and macroscopic vision.

\section{References}

[1] Li, J.L. (2016) Fare to "Parcel Tax", Where Is the Path for Cross-Border E-Commerce-Take the Development of Yiwu Cross-Border E-Commerce as Example. Zhejiang Economy, No. 15, 58-59.

[2] She, J.M. (2015) The Development of Cross Boarder E-Commerce Import Business and Reform of Mail Channel Customs Supervision. Journal of Customs and Trade, No. 2, 70-78

[3] Chen, F.T. (2010) A Preliminary Study to the Customs Postal Supervision: The Angle of New Public Service. Fudan University, Shanghai.

[4] Li, H.L., Cheng, H. and Wong, W. (2016) Study of the Strategy to Achieve Modernization of the Customs Tax Management in the Perspective of Trade Facilitation. Chinese Public Administration, No. 6, 62-66.

[5] Fan, W.C. (2015) The Development to Cross-Border E-Commerce and the Transformation of Foreign Trading Mode in Our Country. Foreign Economic Relations \& Trade, No. 1, 4-7.

[6] Mao, D.G. (2015) Study of the Issues of Customs Tax Levy and Management of Cross-Border E-Commerce. Practice in Foreign Economic Relations and Trade, No. 12, 26-29.

\section{Scientific Research Publishing}

Submit or recommend next manuscript to SCIRP and we will provide best service for you:

Accepting pre-submission inquiries through Email, Facebook, LinkedIn, Twitter, etc. A wide selection of journals (inclusive of 9 subjects, more than 200 journals)

Providing 24-hour high-quality service

User-friendly online submission system

Fair and swift peer-review system

Efficient typesetting and proofreading procedure

Display of the result of downloads and visits, as well as the number of cited articles

Maximum dissemination of your research work

Submit your manuscript at: http://papersubmission.scirp.org/

Or contact ajibm@scirp.org 